\title{
ADVANTAGES AND DISADVANTAGES OF OUTSOURCING ACCOUNTING WORLDWIDE AND IN LATVIA
}

Ivita Faitusa ${ }^{1}$, Dr.oec./ lecturer

${ }^{1}$ University of Latvia

\begin{abstract}
The accounting outsourcing services have not rich experience in Latvia. It started developing in the 1990s, but accounting outsourcing services have different expertise and history in Europe and around the world. An accountant is not a regulated profession in Latvia; an accountant is able to practice without a mandatory accountancy qualification, and it is enough for him/her to have only an economic-related academic or professional certificate, diploma or degree or experience or an accountant leading to a certificate of competency. This research aims to identify main future challenges for outsourcing accounting companies and accountants. The article looks at both theory and practice and attempts to determine and understand problematic issues about the advantages and disadvantages of outsourcing accounting leading to recommendations for improvement. The rapid development of cloud accounting has played an essential role in the development of outsourcing accounting these days. The author found that only in Norway there are specific rules for outsourcing accountants or external accountants. Main advantages of cloud accounting are possibilities of remote work and a universal system for accountants and managers. The author defined three significant questions for the Accounting Outsourcing Survey in Latvia, Lithuania, and Estonia.
\end{abstract}

Keywords: accounting, accounting outsourcing.

JEL code: M41.

\section{Introduction}

Outsourcing services have helped thousands of countries to be profiTable and increase efficiency in Europe. In the paper, the author intends to discuss the historical development of outsourcing accounting companies, cloud accounting as a part of the outsourcing service and as a new paradigm of accounting policies. The development of an accountant's profession is a popular subject in researches in many countries. The author made theoretical research on literature review and developed survey questions for the next research, evaluating outsourcing accountants in the three Baltic States. The main problem is that there are No mandatory requirements regarding education for a practising accountant in Latvia. This research aims to identify main future challenges for outsourcing accounting companies. The scientific literature review and monographic method, economic analysis and synthesis methods, data comparative analysis method, and data analysis of the European Commission regulated professions database are used in this article.

\section{Outsourcing accounting services worldwide and in Latvia}

Any company and even any individual, who carries out an economic activity, must keep an accounting. "Accounting is a system of measurement ('to count') and reporting ('to account for') of economic events for the purpose of decision making." (Stolowy H. \&, Ding Y., 2017).

In general, the main reasons why companies outsource their services are to ensure a high level of productivity and to offer maximum quality to their own customers. The area of outsourced service is vast, including but not limited to business process outsourcing (BPO), human resources services, and information technology (IT) outsourcing. Some of the most outsourced global services are financial accounting services, generating much of Business Process Outsourcing revenue. The largest global payers in this area are Deloitte, PricewaterhouseCoopers, Ernst\&Young, and KPMG constituting the so-called "The Big4" offering services such as accounting, auditing, corporate finance or insurance services (Popovici, Moraru, 2018).

\footnotetext{
${ }^{1}$ E-mail: ivita.faitusa@lu.Iv, phone No +371 26141974
} 
The origins of accounting services in Latvia should be related to Swiss Professor E. Lauris who established the first accounting office in 1901, whereas the offices had already spread all over Europe by the end of the 1930s. Accounting offices carried out accounting for the agricultural and craft companies. In Latvia, the first office of this kind started its activities in 1923, and it provided services to 71 agricultural companies during its first year of operations (Millere, 2011).

Since the Industrial Revolution, companies have grappled with how they can exploit their competitive advantage to increase their markets and their profits. Almost throughout the $20^{\text {th }}$ century, a model was a large integrated company that can "own, manage, and directly control" its assets. In the 1950s and 1960s, the rallying cry was diversification to broaden corporate bases and take advantage of economies of scale. By diversifying, companies expected to protect their profits, even though expansion required multiple layers of management. Subsequently, in the 1970s and 1980s, organisations attempting to compete globally were handicapped by a lack of agility that resulted from bloated management structures. To increase their flexibility and creativity, many large companies developed a new strategy of focusing on their core business, which required identifying critical processes and deciding which of those could be outsourced (SCRC, 2006).

Only in the 1990s, after the restoration of Latvia's independence, the accounting services again could develop as an independent type of business (Sneidere, Bumane, and Lascenko, 2013).

At present, outsourcing has become a global phenomenon that has revolutionised the business environment. Outsourcing is more present than ever, and the type of impact that this field can have on the economy lies with each state. Investing in infrastructure, education, openness to innovation, and innovation itself can make a difference in the long run (Popovici, Moraru, 2018).

The 2016 International Federation of Accountants Global SMP Survey asked practitioners from small and medium-sized practices across the globe about their challenges, how various environmental factors may affect them over the next five years, their 2016 revenues and projected 2017 revenues and the consulting services they provided. It additionally reports on practitioners' views on the impact of challenges that their small and medium-sized corporate customers faced. Besides, it introduced questions on personnel and staffing issues, technology challenges, collection ratios, and employee utilisation ratios (IFAC, 2017).

Data (Fig. 1) enables us to see that respondents rated eight factors to indicate the degree to which they believe each element can impact their practice over the next five years. Consistent with 2014 and 2015, the Regulatory Environment continued to be viewed as the most impactful with $56 \%$ of respondents anticipating that it will have a high or very high impact. Technology developments at $52 \%$ up from $43 \%$ in 2015 were viewed as having the next highest potential impact on SMEs. The percentage of respondents that rated the anticipated implications of Capability to Adapt to New Client Needs as high or very high (45\% up from $36 \%$ in 2015), and Perceived Trust and Credibility of the Profession (43\%, up from $35 \%$ in 2015) increased substantially in comparison to 2015. For all four of the environmental factors noted, sensitivity to the factors increased in 2016, falling more in line with 2014 survey results. (IFAC, 2017). 


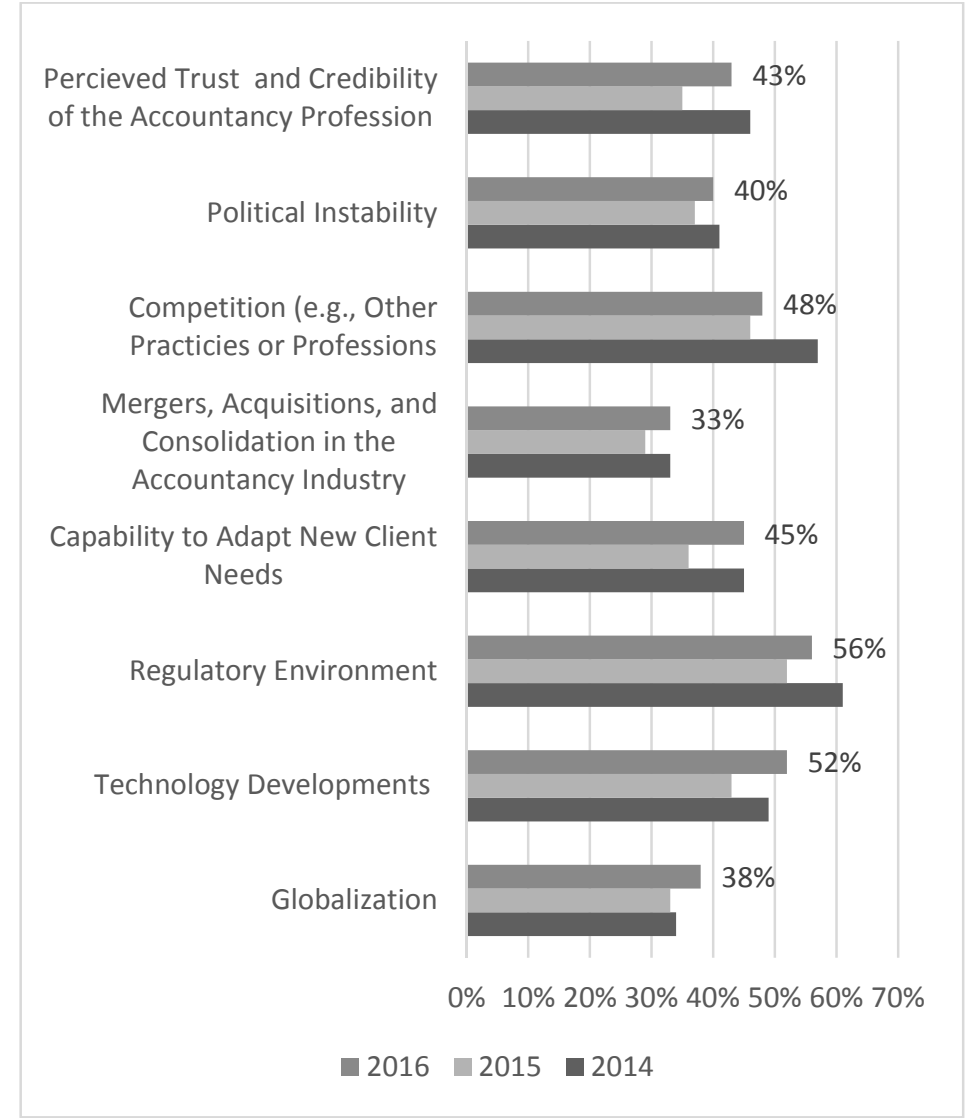

Source: author's construction based on IFAC, 2017

Fig. 1. Factors impacting SMPS over next five years- comparison of 2016, 2015, 2014 (sum of high \& very high impact)

The Framework for International Education Standards for Professional Accountants and Aspiring Professional Accountants (2015) defines such requirements for the accountancy profession: preparing, analysing, and reporting relevant and faithfully represented financial and nonfinancial information; partnering in decision-making and in formulating and implementing organisational strategies; developing and examining relevant tax information (Bruna I. et al, 2017). According to those theoretical statements, the author will analyse the regulation of the accountant's profession as an essential quality provider to ensure accountancy service.

\section{Analysis of accountants' profession in European Countries}

After data analysis of the European Commission regulated professions database (European Commission, 2019), the author found that three different generic names of accountants' professions exist in 18 European Union Member States: 1) Accountant/ Tax Advisor includes 38 regulated professions, 2) Auditor/ Accountant includes 40 regulated professions, and 3) public finance accountants include three regulated professions, which are incorporated in the European database as Auditors and Accountants together. Names of professions differ, and we can find more than 10 types of professions for an accountant (Table 1).

From data (Table 1), we can see that professions are very different, and there are No common names in, for example, the generic name of the profession (auditor/accountant). There are Chartered Accountants and Auditors in Austria, but in the Netherlands, there is auditor/accountant. Moreover, many other differences are observed in European countries.

There are three main types of regulation in European countries: reserves of activities, reserves of activities and protected title, and protected title (without reserves of activities). 
There are three qualification level types: SEC - diploma post-secondary education; PS3 - diploma of the post-secondary level (3-4 years), and attestation of competence just in the Czech Republic.

The author found that there are specific rules for outsourcing accountants just in Norway: external accountants must be authorised by the Financial Supervisory Authority of Norway (Finanstilsynet) and shall conduct their client's duties according to the accounting and bookkeeping legislation. External accountants shall do its business by sound accounting practice. External accountants shall prepare reports and information to their clients that they must provide by law or regulation. These include annual accounts, value-added tax reports, reports for tax and national insurance, etc. (European Commission, 2019).

The author did not find information about the regulation of outsourcing business in Europe and made conclusions that in the countries were regulated accountants' professions were regulated, one for outsourcing companies should be as well.

In Latvia, the Law on Accounting stipulates that "an accountant is an individual, whose qualification corresponds to the fourth or the third level qualification of an accountant determined by the Cabinet of Ministers and whose expertise is attested by a relevant educational document (diploma or certificate) as well as such an individual, whose expertise in relevant accounting issues is certified by experience or an appropriate certificate, and which carries out the duties of an accountant. In his turn, "an outsourced accountant is an individual, who undertakes to provide or provides a customer with an accounting service which meets the requirements of an accountant based on a written agreement with a company (other than an employment contract)" (Saeima, 1992).

In Latvia, there are No mandatory requirements regarding education for a practising accountant. Public authorities of the Republic of Latvia should genuinely look at the accountancy profession to determine the level of qualification and experience required to establish and ensure that skilled accountants manage a company's financial statements (Millere, Faitusa, Grima, Baldacchino, 2018).

Amendments to the Law on Accounting are planned with a licencing program for outsourcing accountants this year.

Like other forms of outsourcing, finance and accounting outsourcing (FAO) has evolved significantly in recent years. These changes centre on three areas. First, the types of finance and administration processes that companies are outsourcing have expanded beyond payables and payroll processing to include processes such as data analyses. Secondly, the management of the relationship between the FAO buyer and the FAO provider has become more efficient. Thirdly, the rise of cloud computing has added new wrinkles not only to FAO relationships but also to the decision of whether to outsource or not (Krell, 2011).

In the next part of the research, the author will find the advantages and disadvantages of cloud accounting or cloud computing as a modern challenge for each accountant. 
Regulated accountants' profession in European Countries in 2019

\begin{tabular}{|c|c|c|c|c|}
\hline State & Profession & $\begin{array}{l}\text { Generic name of } \\
\text { profession }\end{array}$ & Type of regulation & Qualification level \\
\hline \multirow{3}{*}{ Austria } & $\begin{array}{l}\text { Certified Accountant } \\
\text { (Buchhalter) }\end{array}$ & $\begin{array}{l}\text { Public Finance } \\
\text { Accountant }\end{array}$ & Reserves of activities & $\begin{array}{l}\text { DSE - Diploma } \\
\text { (post-secondary } \\
\text { education) }\end{array}$ \\
\hline & $\begin{array}{l}\text { Chartered Accountants } \\
\text { and Auditors }\end{array}$ & Auditor/Accountant & Reserves of activities & $\begin{array}{l}\text { PS3 - Diploma of the } \\
\text { post-secondary level } \\
\text { (3-4 years) }\end{array}$ \\
\hline & $\begin{array}{l}\text { Senior Accountants } \\
\text { Payroll Accountant }\end{array}$ & $\begin{array}{l}\text { Accountant/Tax } \\
\text { advisor }\end{array}$ & Reserves of activities & $\begin{array}{l}\text { DSE - Diploma } \\
\text { (post-secondary } \\
\text { education) }\end{array}$ \\
\hline Bulgaria & $\begin{array}{l}\text { Certified Public } \\
\text { Accountant (auditor) }\end{array}$ & \multirow{5}{*}{ Auditor/Accountant } & Reserves of activities & $\begin{array}{l}\text { PS3 - Diploma of the } \\
\text { post-secondary level } \\
\text { (3-4 years) }\end{array}$ \\
\hline Cyprus & $\begin{array}{l}\text { Certified Public } \\
\text { Accountant }\end{array}$ & & Reserves of activities & $\begin{array}{l}\text { PS3 - Diploma of the } \\
\text { post-secondary level } \\
\text { (3-4 years }\end{array}$ \\
\hline Germany & Accountant & & Undefined & $\begin{array}{l}\text { PS3 - Diploma of the } \\
\text { post-secondary level } \\
\text { (3-4 years) }\end{array}$ \\
\hline Malta & Accountant & & $\begin{array}{l}\text { Reserves of activities } \\
\text { and protected title }\end{array}$ & Not applicable \\
\hline \multirow{2}{*}{ Netherlands } & Auditor/Accountant & & $\begin{array}{l}\text { Reserves of activities } \\
\text { and protected title }\end{array}$ & $\begin{array}{l}\text { PS3 - Diploma of the } \\
\text { post-secondary level } \\
\text { (3-4 years) }\end{array}$ \\
\hline & Auditor/Accountant & \multirow{9}{*}{$\begin{array}{l}\text { Accountant/Tax } \\
\text { advisor }\end{array}$} & $\begin{array}{l}\text { Reserves of activities } \\
\text { and protected title }\end{array}$ & $\begin{array}{l}\text { PS3 - Diploma of the } \\
\text { post-secondary level } \\
\text { (3-4 years) }\end{array}$ \\
\hline Belgium & $\begin{array}{l}\text { Accounting Professional } \\
\text { Accounting } \\
\text { Professionals/Tax-experts } \\
\text { Accountant }\end{array}$ & & $\begin{array}{l}\text { Reserves of activities } \\
\text { and protected title }\end{array}$ & $\begin{array}{l}\text { PS3 - Diploma of the } \\
\text { post-secondary level } \\
\text { (3-4 years) }\end{array}$ \\
\hline $\begin{array}{l}\text { Czech } \\
\text { Republic }\end{array}$ & $\begin{array}{l}\text { Accounting consulting, } \\
\text { bookkeeping, tax } \\
\text { accounting }\end{array}$ & & Reserves of activities & $\begin{array}{l}\text { Attestation of } \\
\text { competence }\end{array}$ \\
\hline France & $\begin{array}{l}\text { Account / chartered } \\
\text { account / bookkeeper / } \\
\text { certified public account }\end{array}$ & & $\begin{array}{l}\text { Reserves of activities } \\
\text { and protected title }\end{array}$ & $\begin{array}{l}\text { PSM - Diploma from } \\
\text { post-secondary level } \\
\text { (more than } 4 \text { years) }\end{array}$ \\
\hline Hungary & Chartered Accountant & & Reserves of activities & $\begin{array}{l}\text { DSE - Diploma } \\
\text { (post-secondary } \\
\text { education }\end{array}$ \\
\hline Iceland & Chartered Accountant & & Reserves of activities & $\begin{array}{l}\text { PS3 - Diploma of the } \\
\text { post-secondary level } \\
\text { (3-4 years) }\end{array}$ \\
\hline Ireland & $\begin{array}{l}\text { Certified Public } \\
\text { Accountant } \\
\text { Chartered } \\
\text { Accountant/Auditor } \\
\text { Incorporated Public } \\
\text { Accountant } \\
\text { Chartered Certified } \\
\text { Accountant }\end{array}$ & & $\begin{array}{l}\text { Accountants designation } \\
\text { is regulated by a } \\
\text { professional body which } \\
\text { is recognised in a } \\
\text { unique form by the } \\
\text { State }\end{array}$ & $\begin{array}{l}\text { PS3 - Diploma of the } \\
\text { post-secondary level } \\
\text { (3-4 years) }\end{array}$ \\
\hline \multirow{2}{*}{ Italy } & $\begin{array}{l}\text { Dottore commercialista- } \\
\text { Accountant }\end{array}$ & & \multirow{2}{*}{ Reserves of activities } & $\begin{array}{l}\text { PSM - Diploma from } \\
\text { post-secondary level } \\
\text { (more than } 4 \text { years) }\end{array}$ \\
\hline & $\begin{array}{l}\text { Esperto contabile- } \\
\text { Accountancy Expert }\end{array}$ & & & $\begin{array}{l}\text { PS3 - Diploma of the } \\
\text { post-secondary level } \\
\text { (3-4 years) }\end{array}$ \\
\hline
\end{tabular}




\begin{tabular}{|c|c|c|c|c|}
\hline \multicolumn{5}{|c|}{ DOI: $10.22616 / E S R D .2019 .130$} \\
\hline State & Profession & $\begin{array}{l}\text { Generic name of } \\
\text { profession }\end{array}$ & Type of regulation & Qualification level \\
\hline Luxemburg & Accountant & & $\begin{array}{l}\text { Reserves of activities } \\
\text { and protected title }\end{array}$ & $\begin{array}{l}\text { SEC - Certificate } \\
\text { attesting the } \\
\text { completion of a } \\
\text { secondary course }\end{array}$ \\
\hline Norway & External Accountant & & Reserves of activities & $\begin{array}{l}\text { PS3 - Diploma of the } \\
\text { post-secondary level } \\
\text { (3-4 years) }\end{array}$ \\
\hline Portugal & Certified Accountant & & $\begin{array}{l}\text { Reserves of activities } \\
\text { and protected title }\end{array}$ & $\begin{array}{l}\text { PS3 - Diploma of the } \\
\text { post-secondary level } \\
\text { ( } 3-4 \text { years) }\end{array}$ \\
\hline \multirow[t]{2}{*}{ Romania } & Licensed Accountant & & \multirow{2}{*}{$\begin{array}{l}\text { Reserves of activities } \\
\text { and protected title }\end{array}$} & $\begin{array}{l}\text { SEC - Certificate } \\
\text { attesting the } \\
\text { completion of a } \\
\text { secondary course }\end{array}$ \\
\hline & Chartered Accountant & & & $\begin{array}{l}\text { PS3 - Diploma of the } \\
\text { post-secondary level } \\
\text { (3-4 years) }\end{array}$ \\
\hline \multirow{3}{*}{$\begin{array}{l}\text { United } \\
\text { Kingdom }\end{array}$} & $\begin{array}{l}\text { Chartered Management } \\
\text { Accountant }\end{array}$ & & $\begin{array}{l}\text { Protected title (without } \\
\text { reserves of activities) }\end{array}$ & $\begin{array}{l}\text { PS3 - Diploma of the } \\
\text { post-secondary level } \\
\text { (3-4 years) }\end{array}$ \\
\hline & $\begin{array}{l}\text { Chartered Public Finance } \\
\text { Accountant }\end{array}$ & & $\begin{array}{l}\text { Protected title (without } \\
\text { reserves of activities) }\end{array}$ & $\begin{array}{l}\text { PS3 - Diploma of the } \\
\text { post-secondary level } \\
\text { ( } 3-4 \text { years) }\end{array}$ \\
\hline & $\begin{array}{l}\text { Chartered Certified } \\
\text { Accountant }\end{array}$ & Auditor/Accountant & $\begin{array}{l}\text { Protected title (without } \\
\text { reserves of activities) }\end{array}$ & $\begin{array}{l}\text { PS3 - Diploma of the } \\
\text { post-secondary level } \\
\text { (3-4 years) }\end{array}$ \\
\hline
\end{tabular}

Source: Developed by the author based on the European Commission regulated professions database, 2019

\section{Cloud accounting advantages}

The study by PricewaterhouseCoopers (2014) shows that although the evaluation trend of cloud technology is significant in the last decade, the accounting standards have evolved too, but without a practical guide for users of cloud applications (Prichici and Ionescu, 2015). In the rapidly changing global economy, robotics process automation has become one of the most critical fastest growing concepts. Digital value co-creation within service businesses and networks sets the value for end customer experience within more efficient operations by focusing on core business development with the use of modern technology (Kedziora and Kiviranta, 2018). Automation has been an essential component of business process management (Laycock and Hartmann, 2005).

With cloud computing, a business can have financial information as of up to the hour, even a minute that can be fully accessible and managed by their accountant. One of the most significant technological trends now is the emergence of cloud technology (Khanom, 2017). Cloud computing is the new paradigm that has changed traditional computer business schemes: static, close, centralised, and proprietary methods cannot cope with the new requirements that have emerged. Still, this new scenario poses some opportunities to use and new problems to be faced (Ruiz-Agundez et al., 2011).

There are three most common myths about cloud accounting. The first myth: storing data on a PC is safer than in the cloud. The third myth: could accounting services are too expensive. For cloud accounting service providers, security is among the critical factors for successful service offering. Huge funds are being invested in setting up data centres and training staff to meet all the security standards set by the European Union and worldwide. The second myth: the data in the cloud are freely accessible to the controlling authorities. In reality, it is impossible both in a legal, practical and moral aesthetic point of view. All legal details are included in an agreement signed between the cloud accounting service provider and a customer. One of the rare occasions, when the controlling authorities have access to the data of a company, is when the employees of the company authorise 
that access during an inspection. The third myth: cloud accounting services are too expensive. The cost of cloud services or the IT structure of an enterprise depends on the corporate data security strategy, business model, and organisational needs. Any enterprise should evaluate whether the enterprise needs to buy its own servers because perhaps other systems will be operated on those servers apart from accounting system or the enterprise can entrust IT server infrastructure to cloud service providers (Slaidins, 2017).

The author agreed with researchers (Slaidins V, 2017.; Prichici and Ionescu, 2015) and concluded the following advantages of cloud accounting as cloud computing allows companies to efficiently and economically:

1) use IT through the model "use as you need and pay as you go";

2) work remotely, because accounting outsourcing provider can connect to a database, view, and enter accounting data of a company;

3) advantages for managers and accountants - an accountant can create a report on different expenses, and a manager will see it in the cloud without additional files and E-mails.

The main disadvantage for cloud accounting will be faced at the places without high-quality Internet or with unsTable Internet and quality of cloud service which depends on experience and technologies.

The accounting profession will face significant changes in the next three decades, and professional organisations, their members, and educational institutions should respond. The three changes, namely, evolving smart and digital technology, continued globalisation of reporting/disclosure standards, and new forms of regulation, are also significant challenges for the profession (Islam, 2017).

\section{Creating questions for survey of outsourcing accountants in the three Baltic States}

After theoretical research, the author continued with one practical issue. The survey is aimed at understanding the specific challenges and opportunities faced by accounting outsourcing companies in Latvia, Lithuania, and Estonia. The author decided to include questions from the 2016 International Federation of Accountants (IFAC) Global SMP Survey (IFAC, 2017); some changes are made to make it more accessible type of survey for small countries.

Question 1. Respondents should report the size of a company: self-employed - one accountant; 2-5 partners and staff; 6-10 partners and staff; 11-20 partners and staff; 21 or more partners and staff.

Question 2. Respondents should report the extent to which their SMEs were presently facing 11 challenges. Challenges include attracting new customers; rising costs; keeping up with new regulations and standards; differentiating from competition; experiencing pressure to lower fees; managing cash flow and late payments, retaining existing customers, serving customers operating internationally; succession planning; personnel and staffing issues; technology developments can be evaluated in scale from low to very high challenge.

Question 3. Respondents should report on technology issues of an accounting company: investing in and staying current with software; achieving a digital, paperless environment; determining what technology is best for the practice; managing privacy and security risks; investing in and staying current with hardware; advances in data analytics, including availability and use of big data; moving to the cloud. 


\section{Conclusions, proposals, recommendations}

1) In Latvia, there are No mandatory requirements regarding education for a practising accountant and outsourcing accountants, accountant's profession is not a regulated profession like in other 18 countries in Europe. The author found that only in Norway there are specific rules for outsourcing accountants or external accountants.

2) Main advantages of cloud accounting are possibilities of remote work and a universal system for accountants and managers. Investments in infrastructure and investments in the education of staff are the most critical factors for improving outsourcing services and be able to implement the latest IT.

3) The author decided to include part of questions from the 2016 International Federation of Accountants Global SMP Survey. The author defined three significant questions for the Accounting Outsourcing Survey in Latvia, Lithuania, and Estonia.

\section{Bibliography}

1. Bruna, I., Senkus, K., Subaciene, R., Sneidere, R. (2017.) Evaluation of Perception of the Accountant's Role at the Enterprise in Latvia and Lithuania. European Research Studies Journal, Volume XX, Issue 3A, pp. 143-163.

2. European Commission (2019). European Commission Regulated Professions. Accountant profession. Retrieved: http://ec.europa.eu/growth/tools-databases/regprof/index.cfm Access:10.02.2019.

3. The 2016 IFAC Global SMP Survey (2017). Retrieved: http://www.ifac.org/system/files/publications/files/2016-IFAC-Global-SMP-Survey.pdf Access: 11.02.2019.

4. International Federation of Accountants (2017). Handbook of International Education Pronouncements. Retrieved: http://www.ifac.org/publications-resources/2017-handbook-international-educationpronouncements. Access 06.02.2019.

5. Islam, M.A. (2017). Future of Accounting Profession: Three Major Changes and Implications for Teaching and Research. Retrieved: https://www.ifac.org/global-knowledge-gateway/businessreporting/discussion/future-accounting-profession-three-major Access: 06.02.2019.

6. Kedziora D., Kiviranta H.M. (2018). Digital Business Value Creation with Robotic Process Automation in Northern and Central Europe. Management Volume 13(2) Summer 2018. pp.161.-174

7. Khanom T. (2017) Cloud Accounting: A Theoretical Overview. IOSR Journal of Business and Management. Volume 19, Issue 6. Ver.V.(June 2017)., pp.31-38.

8. Krell E. (2018) Finance and Accounting Outsourcing Assessing and Planning for Success. Chartered Professional Accountants of Canada. p.19.

9. Millere I., Faitusa I., Grima S., BaldacchiNo P.J. A (2018). Comparative Analysis of the Latvian and Maltese Regulatory and Professional Requirements for Accountants. New Challenges of Economic and Business Development - 2018: Productivity and Economic Growth: International Scientific Conference, May 10-12, 2018, Riga, Latvia: Proceedings Riga: University of Latvia, 2018. pp.463-473

10. Millere I. (2011). Gramatvedibas attistiba Latvija. LU Akademiskais apgads, pp.181.-182.

11. Popovici N., Moraru C. (2018). Outsourcing Management: Outsourcing Services Worldwide and in Romania. "Ovidius" University Annals, Economic Sciences Series. Volume XVIII, Issue 1/2018.

12. Prichici C., Ionescu B.S. (2015) Cloud Accounting-a New paradigm of Accounting Policies. SEA- Practical Application of Science. Volume III, Issue I (7)/2015. pp.489-496.

13. Ruiz-Agundez I., Penya Y.K., Bringas P.G. (2011). A Flexible Accounting Model for Cloud Computing. Conference paper. May 2011. Retrieved: http://www.researchgate.net/publication/224248659. Access: 12.02.2019.

14. Saeima (1992). LR Law "On Accounting" (with amendments to 01.01.2018). Retrieved: https://likumi.lv/ doc.php?id=66460. Access: 06.02.2018.

15. Slaidins V. (2017). Makonpakalpojumi gramatvediba - miti un realitate. Bilance Nr.20 (416) Oktobris 16, 2017., pp.24.-27.

16. Sneidere R., Bumane I., Lascenko J. (2013). Accounting Outsourcing Services in Latvia: Problems and Possible Solutions. Economics and Management:2013 18(1), p.26.-38.

17.SCRC (Supply Chain Resource Cooperative) SME (2006). A Brief History of Outsourcing. June 1, 2006. Retrieved: https://scm.ncsu.edu/scm-articles/article/a-brief-history-of-outsourcing. Access:10.02.2019.

18. Stolowy, H. \&, Ding, Y. (2017). Financial Accounting and Reporting: a Global Perspective. 5th Edition. Hampshire, United Kingdom, Cengage Learning EMEA, p. 660. 